\title{
A contribuição dos instrumentos de investigação de Joseph Renzulli para a identificação de estudantes com Altas Habilidades/Superdotação
}

Angela Mágda Rodrigues Virgolim*

\section{Resumo}

O Modelo de Enriquecimento Escolar (The Schoolwide Enrichment Model - SEM), é resultado do trabalho pioneiro do Dr. Joseph Renzulli na década de 70, validado por mais de vinte anos de pesquisas empíricas. Este Modelo se encontra ancorado em três pilares: (a) O Modelo dos Três Anéis, que basicamente fornece os pressupostos filosóficos utilizados pelo SEM; (b) o Modelo de Identificação das Portas Giratórias, que fornece os princípios para a identificaçáo e formação de um Pool de Talentos, e (c) o Modelo Triádico de Enriquecimento, que implementa as atividades de Enriquecimento para todos os alunos no contexto escolar. O presente artigo tem como objetivo focalizar o Modelo de Enriquecimento Escolar nos seus aspectos de concepção, identificação e avaliação da superdotação, apresentando os principais instrumentos utilizados por Renzulli para cada um destes propósitos. São apresentados formulários para a indicação de alunos para a composição do Pool de Talentos; para a indicação de áreas e/ou disciplinas nas quais o aluno demonstra um grande interesse; e para se obter informaçôes sobre os interesses, aptidões e estilos de aprendizagem dos estudantes. Capitalizando sobre estas informaçóes o professor se encontra em posição de poder fornecer a eles opçóes educacionais bem planejadas que possam levar ao adequado desenvolvimento de suas potencialidades latentes, emergentes e manifestas.

Palavras-chave: Modelo de Enriquecimento Escolar; Identificação;

Enriquecimento.

* Professora Doutora da Universidade de Brasília (UnB). Brasília, Distrito Federal, Brasil. 


\section{The Contribution of the Research Instruments of Joseph Renzulli for the Identification of Gifted and Talented Students}

\section{Abstract}

The Schoolwide Enrichment Model - SEM, is the result of Dr. Joseph Renzulli's pioneering work in the 70s, validated by over twenty years of empirical research. This model is based on three pillars: (a) The Three-Ring Conception of Giftedness, which basically provides the philosophical assumptions used by SEM; (b) The Revolving Door Identification Model, which provides the principles for the identification and training of a Talent Pool; and (c) The Enrichment Triad Model, which implements enrichment activities for all students in the school context. This article aims to focus the Schoolwide Enrichment Model in its aspects of conception, identification and assessment of giftedness, including the main instruments used by Renzulli for each of these purposes. Forms for teachers, students and parent nominations for the composition of the Talent Pool are presented; for the indication of areas and/or disciplines where the student demonstrates a great interest; and to obtain informations about the students' interests, abilities and learning styles. Capitalizing on this information, the teacher is in a position to provide them with thoughtful educational options that can lead to a proper development of their emerging, latent and manifest potential.

Keywords: Schoolwide Enrichment Model; Identification; Enrichment.

\section{Introdução}

Um dos grandes passos dados no Brasil em direção a uma Política Nacional de Educação Especial foi, sem dúvida alguma, a implementação dos Núcleos de Atividades de Altas Habilidades/Superdotação (NAAH/S) pelo Ministério da Educação em 2005. O programa, desenvolvido em todas as unidades da Federação, em parceria com as Secretarias de Educação, tornou-se tema amplamente debatido em seminários, encontros, congressos e cursos para a formação continuada de professores da educação inclusiva. Em 2007, com o intuito de subsidiar as açôes voltadas para a área e difundir informaçóes para auxiliar nas práticas de atendimento ao aluno com altas habilidades/superdotação, a Secretaria de Educação Especial do MEC publicou uma série de quatro volumes de livros didático-pedagógicos denominados " $A$ construção de Práticas Educacionais para Alunos com Altas Habilidades/Superdotação"." Com estes volumes, o MEC visava, basicamente, oferecer atendimento educacional especializado com atividades suplementares para: (a) aprofundar e enriquecer o currículo, com vistas a ampliar e diversificar os conhecimentos que despertam curiosidade e interesse nos alunos; (b) promover a inclusão educacional e social; (c) estimular o pensamento produtivo; (d) desenvolver potencialidades e habilidades específicas; (e) propiciar experiências de resolução de problemas, formulação de hipóteses, e (f) promover o ajustamento de diferentes áreas de desenvolvimento (BARBOSA, 2007). 
Buscando um aporte teórico que abarcasse todas essas possibilidades, o MEC adotou então o Modelo de Enriquecimento Escolar (The Schoolwide Enrichment Model-SEM), resultante do trabalho pioneiro do Dr. Joseph Renzulli na década de 70, validado por mais de vinte anos de pesquisas empíricas (RENZULLI \& REIS, 2000). Este Modelo se encontra ancorado em três pilares: (a) O Modelo dos Três Anéis, que basicamente fornece os pressupostos filosóficos utilizados pelo SEM; (b) o Modelo de Identificaçáo das Portas Giratórias, que fornece os princípios para a identificação e formação de um Pool de Talentos, e (c) o Modelo Triádico de Enriquecimento, que implementa as atividades de Enriquecimento para todos os alunos no contexto escolar.

O presente artigo tem como objetivo focalizar o Modelo de Enriquecimento Escolar, nos seus aspectos de concepção, identificação e avaliação da superdotação, apresentando os principais instrumentos utilizados por Renzulli para tais propósitos.

\section{Dois tipos de superdotação}

Segundo Renzulli (1986b; 2005), as habilidades superiores podem ser divididas em duas amplas categorias distintas: a superdotaçáo escolar e a superdotação criativo-produtiva.

A superdotação escolar é, também, conhecida como a "habilidade do teste ou da lição de aprendizagem", pois é o tipo mais facilmente identificado pelos testes de QI para a entrada nos programas especiais. As habilidades medidas nos testes de QI são as mesmas exigidas nas situaçóes de aprendizagem escolar; desta forma, o aluno com alto QI também tende a obter boas notas na escola. A ênfase, neste tipo de habilidade escolar, recai sobre os processos de aprendizagem dedutiva, treinamento estruturado nos processos de pensamento, e aquisiçáo, estoque e recuperaçáo da informação.

Já a habilidade criativa-produtiva implica no desenvolvimento de materiais e produtos originais; aqui, a ênfase é colocada no uso e aplicação da informaçáo (conteúdo) e processos de pensamento de forma integrada, indutiva, e orientada para os problemas reais. $\mathrm{O}$ aluno, nesta abordagem, é visto como um "aprendiz em primeiramão", no sentido de que ele trabalha nos problemas que têm relevância para ele e são considerados desafiadores (RENZULLI, 1986b).

Além disso, Renzulli (2005) advoga pelo aumento das chances do aluno desenvolver suas habilidades de pensamento criativo de forma mais completa, ou seja, desenvolvendo ideias e produtos que realmente venham a ter impacto nos outros e causar mudanças duradouras. $\mathrm{O}$ autor aponta que, historicamente, as pessoas criativas e produtivas do mundo têm sido os produtores de conhecimento, mais do que os consumidores de conhecimento, os reconstrutores do pensamento em todas as áreas do esforço humano; também são eles comumente reconhecidos como "verdadeiramente superdotados". O autor acentua ainda que "a História não se lembra de pessoas que meramente obtiveram altos resultados nos testes de QI ou daqueles que aprenderam bem suas liçóes mas náo aplicaram seu conhecimento de forma inovadora e orientada para a ação.”(p. 256) 


\section{Modelo dos Três anéis}

Em sua Teoria dos Três Anéis (RENZULLI; REIS, 1997), concebe a superdotação como os comportamentos que resultam da confluência entre altas habilidades, criatividade e envolvimento com a tarefa. Os três anéis estão dispostos em um padrão xadrez (ver Fig. 1) que representa a interação entre fatores ambientais e de personalidade que favorecem o aparecimento da superdotação (representada na parte hachureada no Modelo). Para Renzulli, este fenômeno se dá no espectro do desenvolvimento humano e pode ser entendido por meio dos comportamentos observáveis apresentados pelo indivíduo em uma dada situação, quando o potencial é convertido em desempenho em uma área específica (RENZULLI, 2005).

\section{Representação gráfica da definição de superdotação}

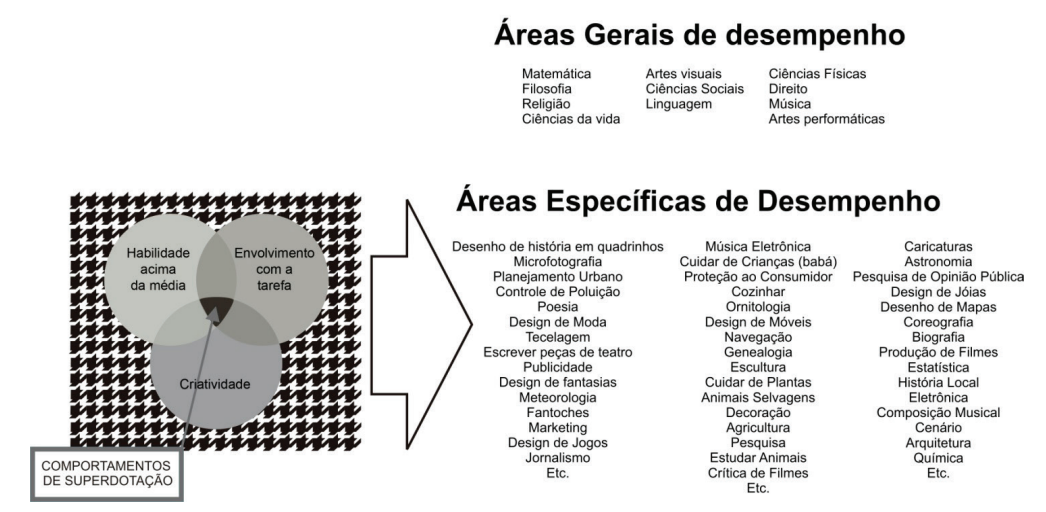

Figura 1. Representação gráfica da definição de superdotação (RENZULLI; REIS, 1997). Figura traduzida e adaptada por Virgolim (2007b) e reproduzida com a autorização dos autores.

Renzulli observa que alunos que possuem pelo menos uma habilidade bem acima da média (mas não necessariamente muito superior) e que demonstram um alto nível de energia e envolvimento com a atividade, desenvolvendo-a de forma criativa, são as pessoas que têm maior probabilidade de exibir comportamentos de superdotação. O autor observa que este conjunto de traços tem um papel decisivo na produçáo criativo-produtiva daquelas pessoas que foram capazes de dar uma contribuição ímpar à humanidade.

A habilidade bem acima da média pode ser definida de duas formas. Habilidades Gerais são traços que podem ser aplicados em todos os domínios (como por exemplo, a inteligência geral), ou a domínios mais amplos (como por exemplo, habilidade verbal geral aplicada a várias dimensóes da área da linguagem). Estas habilidades consistem na capacidade de processar informaçóes, de integrar experiências que resultem em respostas apropriadas e adaptáveis a novas situações, e de se engajar em pensamento abstrato. Exemplos de habilidade geral seriam o raciocínio verbal e numérico, relaçóes espaciais, memória e raciocínio por palavras, habilidades usualmente medidas em testes de aptidão e inteligência (RENZULLI, 2005). 
As Habilidades especificas se referem à habilidade de adquirir conhecimento ou técnica, ou a habilidade de desempenhar uma ou mais atividades especializadas; consistem na habilidade de aplicar várias combinaçóes das habilidades gerais a uma ou mais áreas especializadas do conhecimento ou do desempenho humano, como dança, química, liderança, matemática, composição musical, administração etc.

Assim, quando Renzulli (2004b) usa o termo "habilidade acima da média", ele se refere a ambos os tipos de habilidades, sejam gerais ou específicas, que deveser interpretado como o domínio superior do potencial em alguma área específica. Desta forma, o termo se refere a pessoas que possuem a capacidade já desenvolvida ou o potencial para desenvolver habilidades em uma determinada área do desenvolvimento.

Um segundo conjunto de traços que consistentemente tem sido encontrado em pessoas criativo-produtivas diz respeito a um tipo de motivaçáo refinada ou focalizada na tarefa em questáo, a que Renzulli e Reis (1997) denominam "envolvimento com a tarefa”. Enquanto a motivação é geralmente definida em termos de um processo geral de energia que desencadeia reaçóes do organismo, envolvimento com a tarefa se refere à energia exercida em um problema particular ou área específica de desempenho. Termos como perseverança, resistência, trabalho árduo, prática dedicada, autoconfiança, crença na própria habilidade de desenvolver um trabalho importante e ação específica aplicada à área de interesse são geralmente utilizados para descrever o envolvimento com a tarefa (RENZULLI, 2005). Pesquisas têm demonstrado que a motivaçáo intrínseca, a fascinaçáo ou motivação para se engajar em atividades primariamente pelo seu próprio valor, é invariavelmente referida como um dos precursores do trabalho distinto e original (AMABILE, 1996; BLOOM \& SOSNIAK, 1982; RENZULLI, 2005).

O terceiro conjunto de traços que caracterizam as pessoas com altas habilidades/superdotação é, geralmente, agrupado sob a denominação de "criatividade". Embora seja um termo amplo e de difícil definição, por envolver inúmeras variações, a criatividade, em geral, envolve a originalidade (ou novidade) e a efetividade (ou utilidade, aplicaçáo). Um produto criativo deve servir para algum propósito, como resolver um problema (RUNCO, 2009). O processo criativo tem sido explicado como a convergência de três fatores: (a) Fatores de atenção: maior abertura ou receptividade, tanto em relaçáo ao ambiente quanto ao mundo interno (pensamentos e idéias); (b) Fatores motivacionais: maior predisposição para desafiar o status quo e produzir produtos originais, e (c) Fatores de Habilidade: maiores níveis de habilidade cognitiva e capacidade de expressar idéias complexas e incomuns (CHAMORRO-PREMUZI, 2009).

O Modelo dos Três Anéis enfatiza que: (1) Os comportamentos de superdotação podem se manifestar mesmo quando os três conjuntos de traços não estáo presentes ao mesmo tempo. O autor deixa claro que nenhum deles é mais importante que o outro, podendo ser utilizados separadamente para a indicaçáo de uma criança para o programa de altas habilidades (RENZULLI \& REIS, 1997; RENZULLI, REIS \& SMITH, 1981); (2) Embora os comportamentos de superdotação sejam influenciados tanto por fatores de personalidade (como auto-estima, auto-eficácia, coragem, 
força do ego, energia, etc.) quanto por fatores ambientais (nível sócio-econômico, personalidade e nível educacional dos pais, estimulação dos interesses infantis, fatores de sorte etc.), assim como por fatores genéticos, ainda assim podem ser modificados e influenciados positivamente por experiências educacionais bem planejadas (GUBBINS, 1982; RENZULLI, 1985; REIS \& RENZULLI, 1982; RENZULLI \& REIS, 1997), e (3) Criatividade e envolvimento com a tarefa são traços variáveis, não permanentes, que podem estar presentes em maior ou menor grau, dependendo da atividade. Mesmo que uma pessoa tenha frequentemente muitas ideias criativas e demonstre bastante energia e envolvimento na maioria das situaçóes, é natural que sua produção criadora sofra variaçóes. Nota-se, também, que, quase sempre, um traço estimula o outro. Ao ter uma ideia criativa, a pessoa se sente encorajada e é reforçada por si mesma e pelos outros; ao colocar sua ideia em ação, seu envolvimento com a tarefa começa a emergir. Da mesma forma, um grande envolvimento para se resolver uma situação-problema pode ativar o processo de resolução criativa de problemas (RENZULLI \& REIS, 1997).

Renzulli $(1978,2004)$ postula que os comportamentos de superdotação podem ser desenvolvidos em certas pessoas em alguns momentos de sua vida, e não em todas as pessoas e nem em todos os momentos - o que implica em uma visão bem situacional da superdotação. Assim, uma criança pode mostrar seu conhecimento adquirido em um dado momento de sua vida escolar - por exemplo, lendo precocemente, ou mostrando um interesse aprofundado por uma disciplina em particular -e náo demonstrar o mesmo interesse ou habilidades em momentos posteriores. Desta forma, para Renzulli, a superdotação não é um conceito estático (isto é, tem ou não se tem), e sim um conceito dinâmico - ou seja, algumas pessoas podem apresentar um comportamento de superdotação, em algumas situaçóes de aprendizagem/desempenho, mas não em todas as situaçôes. É, neste contexto, que Renzulli defende a ideia de que não devemos rotular o aluno como sendo ou não sendo superdotado, mas tentarmos entender que as altas habilidades aparecem em um continuum de habilidades. Neste sentido, são características que existem em todos os seres humanos, mas diferindo em níveis, intensidades e graus de complexidade em cada um. Esta concepção deixa bem claro que as altas habilidades/superdotação envolvem aspectos tanto cognitivos quanto de personalidade do indivíduo, nos quais os talentos emergem a medida em que as diferentes habilidades (latentes ou manifestas) de uma pessoa são reconhecidas e apresentadas, de forma criativa, em situaçóes nas quais o indivíduo percebe-se motivado a desenvolver suas capacidades em altos níveis. A Fig. 2 mostra uma analogia entre as habilidades latentes, emergentes e manifestas e o crescimento de uma planta, embora alguns talentos possam estar ainda latentes na época da indicaçáo do aluno para a sala de recursos, torna-se meta do programa oferecer recursos para que estes e outros talentos possam se tornar manifestos (GUBBINS, 2005). 


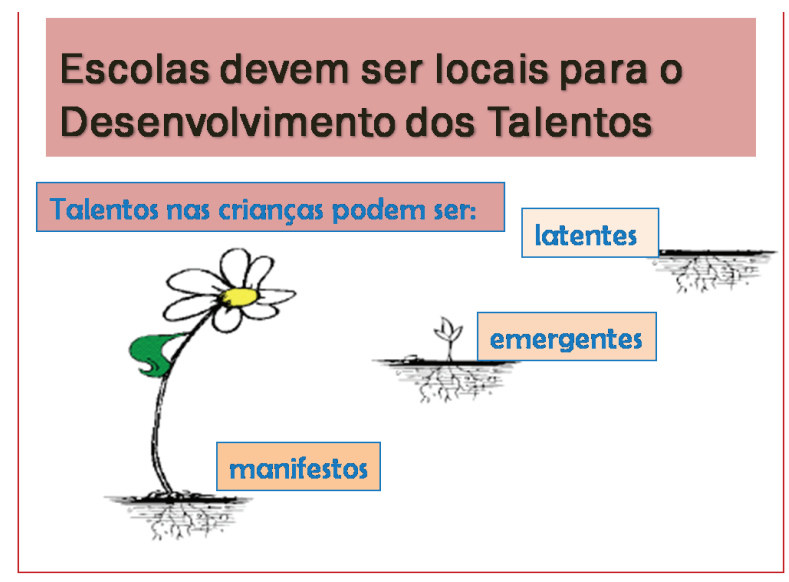

Renzulli, 2004

Figura 2. Estágio do Desenvolvimento dos Talentos. Gubbins, 2005. Figura traduzida e adaptada por Virgolim (2007a) e reproduzida com a autorização dos autores.

Assim sendo, passamos a entender que, nesta equação, as altas habilidades/ superdotação resultam diretamente do grau em que uma determinada habilidade é apreendida, interiorizada e expressa; do nível de motivação que o indivíduo revela ao desempenhar tarefas em áreas específicas, e do grau de originalidade que suas ideias podem trazer ao campo. Torna-se, portanto, tarefa da escola estimular, em todos seus alunos, o desenvolvimento e a expressão do talento criador e da inteligência, e não só naqueles que possuem um alto QI ou que tiram as melhores notas no contexto acadêmico; desenvolver comportamentos superdotados em todos aqueles que têm potencial; nutrir o potencial da criança, rotulando o serviço, e náo o aluno; desenvolver uma grande variedade de alternativas ou opçóes para atender as necessidades de todos os estudantes (TREFFINGER \& RENZULLI, 1986). Essa noção tem um impacto direto para a sala de aula regular, estabelecendo sua responsabilidade em desenvolver um currículo adequado e inclusivo, que atinja todos os alunos, inclusive os que apresentam altas habilidades/superdotação.

\section{Modelo de Identificação das Portas Giratórias}

O Modelo das Portas Giratórias (que se relaciona com as questóes de como identificar e selecionar o aluno que apresenta altas habilidades) foi concebido para facilitar a seleção do grupo de alunos que fará parte do chamado "Pool de Talentos"; ou seja, se um aluno exibe comportamentos de superdotação (habilidade superior em alguma área; envolvimento com a tarefa; e criatividade) em relação a uma área particular ou tópico de estudo, ele poderá, por algum tempo, desenvolver este interesse ou tópico com maior profundidade em uma sala de recursos. O Modelo sugere que o primeiro passo a ser seguido pela equipe de diagnóstico para a implementação deste modelo é identificar o grupo de estudantes que farão parte do Pool de Talentos, o que pressupóe, segundo Renzulli e Reis (1997), seis passos principais: 
(1) Indicação por meio de testes: a inclusão de alunos no Pool de Talentos deve ser garantida a qualquer aluno que obtiver um resultado acima da média em testes de inteligência, como por exemplo, no Teste Matrizes Progressivas de Ravenou na Escala de Inteligência Wechsler para Crianças - WISC, que são os testes mais amplamente utilizados no contexto brasileiro. Observa-se que os testes de inteligência são muito importantes basicamente em duas situaçôes: (a) para a identificação de talentos na área acadêmica (uma vez que não são adequados para a identificação de talentos em outras áreas, como por exemplo, a artística, a liderança, a criativa e a psicomotora), e (b) para a identificaçấo daqueles alunos que possuem um QI acima da média, mas passam despercebidos devido ao baixo rendimento escolar, expresso por notas baixas e pouca frequência às aulas. Isto acontece, na maioria das vezes, quando o aluno se torna desmotivado com o ensino, com o currículo, com professores pouco criativos ou com as poucas oportunidades de escolha que existem em escolas que seguem um ensino mais tradicional. Além disso, alunos que apresentam concomitantemente às altas habilidades o Transtorno de Déficit de Atenção, Síndrome de Asperger, Dislexia ou outros problemas de aprendizagem, ou ainda que apresentam deficiência visual ou auditiva podem ter problemas no diagnóstico da superdotação devido às baixas notas que podem vir a apresentar. Seeley (1993) ressalta que boa parte do fracasso escolar do aluno pode ser devido ao fracasso da própria escola em prover ambientes de aprendizagem apropriados para as crianças, respeitando seus diferentes estilos de aprendizagem. Whitmore (1986) chama a atenção para o fato de que toda criança ou jovem gosta de aprender e de se sair bem na escola e, principalmente, no caso dos superdotados, de buscar a excelência em alguma área do conhecimento valorizada pessoal e socialmente. Contudo, em um ambiente onde suas reais necessidades não são atendidas, a sua tendência é deslocar sua motivação das atividades escolares para outras atividades que lhes são mais compensadoras, tais como interação social e devaneio. Também, Alencar e Virgolim (2001) pontuam que a escola ainda não está preparada para lidar com as necessidades especiais dos alunos com habilidades intelectuais superiores. Como resultado, os alunos podem apresentar comportamento social inadequado, hostilidade, agressão com relação aos outros e delinquência social; e podem desenvolver um autoconceito negativo, insegurança e sentimentos gerais de inadequaçáo, expressando, dessa forma, sua frustração diante de um programa acadêmico repetitivo e monótono, que pouco favorece a expressão do potencial superior (ALENCAR \& VIRGOLIM, 2001; BUTLER-POR, 1993; GALBRAITH \& DELISLE, 1996; LANDAU, 1990; WINNER, 1998). Torna-se, portanto, de especial importância compreender que a falha em identificar corretamente e atender às necessidades especiais desta populaçáo pode colocar o aluno em risco de fracasso escolar e comprometer seriamente tanto o seu desenvolvimento cognitivo, quanto emocional, impedindo-o de realizar plenamente o seu potencial (NEIHART, REIS, ROBINSON \& MOON, 2002).

A par dessas consideraçóes, lembramos que as modernas teorias da inteligência não percebem que a habilidade superior possa ser medida apenas por testes psicométricos (VIRGOLIM, 2009), já que estes abarcam apenas 1 a 3\% da população. Quando incluímos outros aspectos à avaliação de superdotados, como, por exemplo, 
liderança, criatividade, competências psicomotoras e artísticas, as estatísticas sobre altas habilidades aumentam significativamente, chegando a abarcar uma porcentagem de 15 a 30\% da população (RENZULLI, 2004b; VIRGOLIM, 2007a). Assim, torna-se essencial a utilização de técnicas mais apuradas de identificação, instrumentos mais amplos e precisos de diagnóstico e bons programas de desenvolvimento e estimulação do potencial destas crianças, para que possamos estabelecer políticas de aproveitamento de talentos e competências em nosso país (VIRGOLIM, 2007b, 2009). É o que é proposto a partir da utilização de formas alternativas de identificação, ressaltadas nos itens a seguir.

(2) Indicaçáo de professores: por sua proximidade com os alunos, os professores podem recomendar para o programa aqueles alunos que demonstram outras características que não aquelas tradicionalmente acessadas por testes de inteligência - por exemplo, criatividade, liderança, aptidão para esportes, para artes cênicas, visuais, dança e música. Um instrumento útil na indicação de alunos para o Pool de Talentos e que fornece uma fonte sistemática de informação sobre o estudante é a Escala para Avaliação das Características Comportamentais dos Alunos com Habilidades Superiores - SCRBSS, publicada originalmente por Renzulli, Smith, White, Callahan e Hartman (1976). Esta escala tem o propósito de ajudar o professor em sala de aula a avaliar as características comportamentais de seus alunos em 10 áreas: criatividade, liderança, motivação, aprendizagem, artes cênicas e plásticas, música, planejamento e comunicação (expressão e precisão). Além de oferecer mais segurança ao professor na composição do Pool de Talentos, a escala permite levantar informações sobre as áreas fortes ou de destaque do estudante, possibilitando o desenvolvimento de atividades mais adequadas para o estímulo do seu potencial (RENZULLI, HARTMAN \& CALLAHAN, 1971). Cada escala apresenta uma lista de comportamentos que o professor assinala de acordo com a assiduidade observada da característica (raramente ou nunca; ocasionalmente; em um grau considerável; todo o tempo). As escalas são pontuadas separadamente para se obter estimativas do professor quanto às características de cada aluno nas 10 áreas, de forma que uma rápida olhada nas características mais assinaladas como "observadas o tempo todo", já dá ao professor uma idéias das áreas em que o aluno mais se sobressai.

Mais recentemente, Renzulli publicou uma versão reduzida desta escala $-a$ Escala para Avaliação das Características Comportamentais dos Alunos com Habilidades Superiores - Revisada (RENZULLI, SMITH, WHITE, CALLAHAN, HARTMAN, \& WESTBERG, 2002), composta por quatro áreas: aprendizagem (que avalia itens como: vocabulário avançado para sua idade ou série; facilidade para lembrar informações; grande estoque de informaçôes sobre um tópico específico; entendimento de material mais complicado através de raciocínio analítico); criatividade (itens como: habilidade de produzir respostas incomuns, únicas ou inteligentes; habilidade de gerar um grande número de idéias ou soluçôes para problemas e questóes; habilidade de pensamento imaginativo; senso de humor; atitude não conformista, não temendo ser diferente); motivação (habilidade de se concentrar intencionalmente em um tópico por um longo período de tempo; interesse constante por certos tópicos ou problemas; compromisso com projetos de longa duração, quando interessado em um tópico; 
pouca necessidade de motivação externa para finalizar um trabalho que inicialmente se mostrou estimulante), e liderança (habilidade de articular ideias e de se comunicar bem com os outros; tendência de direcionar as atividades quando está envolvido com outras pessoas; comportamento responsável - pode-se contar com ele para terminar as atividades ou projetos que começou).

Feldhusen e Jarwan (1993) salientam que a precisão dos julgamentos de professores na identificação de alunos superdotados pode ser aumentada através de treinamento apropriado, incluindo esclarecimentos sobre o processo de identificaçáo, discussão dos objetivos dos programas especiais e procedimentos utilizados. Estes autores também ressaltam a necessidade de se usar formulários e escalas fidedignos e válidos, desenvolvidos e cuidadosamente aperfeiçoados através de pesquisas empíricas e testados na prática.

(3) Caminhos Alternativos: Para a composição do Pool de Talentos também se utilizam indicaçôes feitas pelos pais, colegas ou, em casos dos mais velhos, pelo próprio aluno. Nestes casos, pais ou alunos devem preencher o formulário de nomeaçáo mais adequado, fornecido pela escola, e encaminhá-lo à equipe de diagnóstico; esta se encarregará de fazer entrevistas com o aluno e seus pais, e administrar os instrumentos que julgarem necessários para complementar a avaliação diagnóstica.

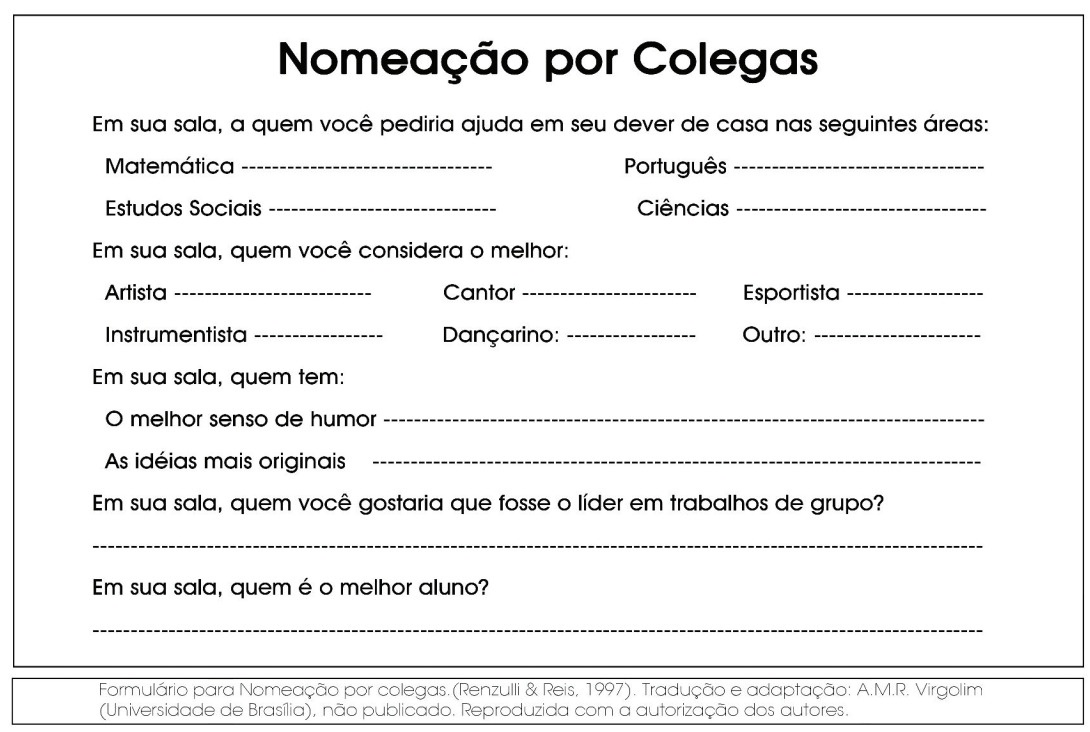

Figura 3. Formulário para Nomeação por colegas (Renzulli \& Reis, 1997). Instrumento traduzido e adaptado por Virgolim, não publicado. Reproduzida com a autorização dos autores. 


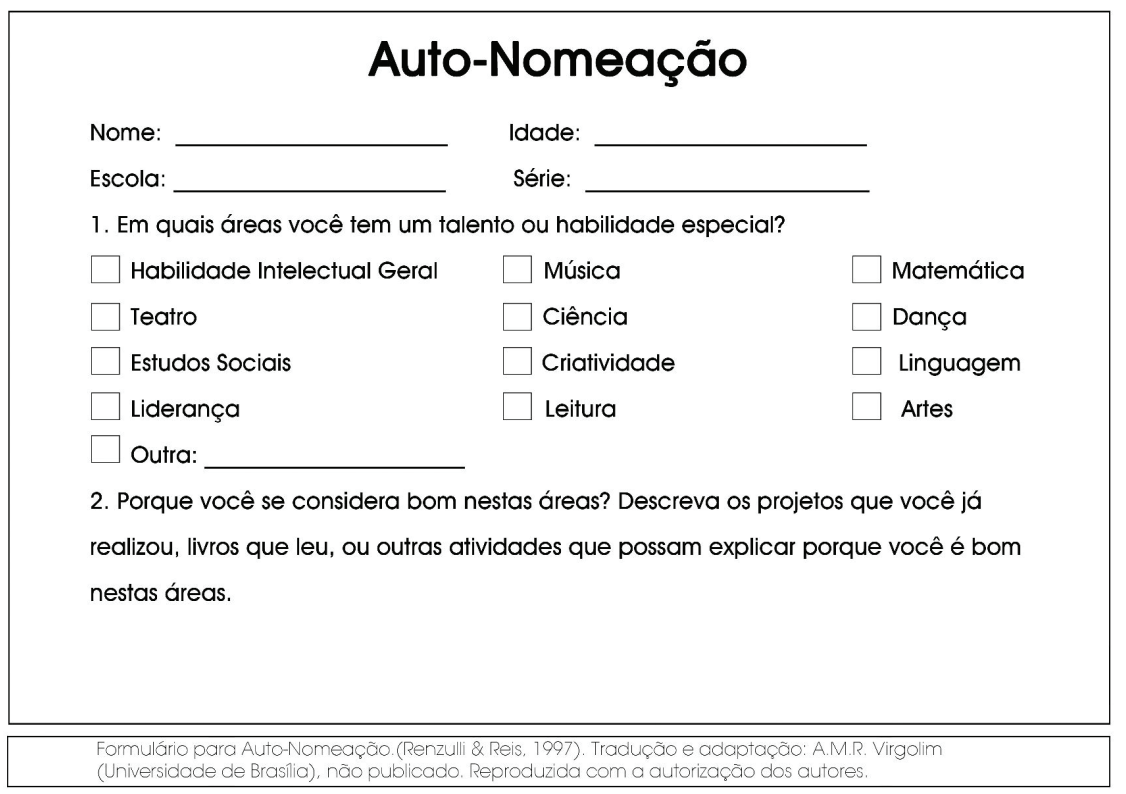

Figura 4. Formulário para Auto-Nomeaçăo.(RENZULLI \& REIS, 1997). Instrumento traduzido e adaptado por Virgolim, náo publicado.Reproduzida com a autorização dos autores.

Nesta etapa também se utilizam testes de criatividade para incluir alunos criativos, que tradicionalmente não são percebidos como superdotados no ambiente escolar, por apresentar traços às vezes indesejáveis neste contexto. Embora, em geral, este aluno seja curioso e imaginativo, com inclinação para brincar com ideias e dar respostas bem humoradas e diferentes do usual, o estudante criativo, muitas vezes, é percebido como o palhaço da turma, crítico de si mesmo e dos colegas, sarcástico, bagunceiro, não-conformista, desrespeitoso para com as figuras de autoridade $\mathrm{e}$ para com as tradições (CLARK, 1992). Muita atenção deve ser dada à identificação do aluno altamente criativo. Segundo Butler-Por (1993), este aluno encontra-se em risco de fracasso escolar, pois pode encontrar relutância em seu ambiente para aceitar seu pensamento divergente e inconformismo, geralmente fonte de tensão e conflito com seus pais e professores.

No entanto, os testes de criatividade devem ser utilizados com a intenção de se obter um amplo conhecimento do perfil do aluno e guiar a aplicação de planos instrucionais mais adequados às suas características e necessidades individuais. Além disso, há evidências de pesquisa que demonstram que a criatividade e a inteligência, embora sejam construtos diferentes, estão correlacionadas quando medidas por testes tradicionais (VIRGOLIM, 2005, 2009). Desta forma, profissionais, no campo da educação, devem promover ao máximo o desenvolvimento de ambos os processos; 
e encorajar alunos a expressar plenamente suas habilidades criativas e intelectuais, conforme nos lembra Treffinger e Renzulli (1986). Assim, em adição aos testes, é também importante observar o comportamento da criança ou jovem quando entretidos com atividades de criação; coletar amostras dos seus produtos mais criativos; e encorajá-la a usar o pensamento divergente, imaginativo e original.

Renzulli (1986a) desenvolveu, em três volumes (MARK, 1, 2 e 3), o programa denominado "Novas Direçôes em Criatividade", com a intenção de dar ferramentas ao professor para desenvolver as habilidades de pensamento criativo de alunos do Ensino Fundamental. Baseado no Modelo da Estrutura do Intelecto, de Guilford, os exercícios exploram a Fluência (habilidade de gerar um grande fluxo de ideias, possibilidades, consequências e objetos); a Flexibilidade (habilidade de usar muitas e diferentes abordagens ou estratégias para resolver um problema; de mudar a direção do pensamento de forma a modificar uma dada informação); a Originalidade (habilidade de produzir respostas únicas e raras), e a Elaboraçáo (habilidade de expandir, desenvolver, particularizar e embelezar ideias, estórias e ilustraçôes)(pag. 4).

No livro Toc, toc, Plim, Plim! Lidando com as Emoçóes, Brincando com o Pensamento através da Criatividade (VIRGOLIM, FLEITH, \& NEVES-PEREIRA, 1999), as autoras também propóem uma série de atividades para estimular a originalidade, fluência e flexibilidade do pensamento. Por exemplo, no exercício "O que aconteceria se...", o aluno é convidado a pensar no maior número de consequências diferentes e bem humoradas para situaçôes inusitadas, como: "e se não houvesse mais leis?"; "e se você diminuísse de tamanho e ficasse com um centímetro de altura?"; "e se você pudesse entrar em uma história em quadrinhos?". No exercício "Brincando com história de fadas", ele deve pensar em uma historinha de fadas e contá-la sob outro ponto de vista (por exemplo, a história do Chapeuzinho Vermelho do ponto de vista do caçador ou da vovó); ou a pensar no que aconteceu depois (por exemplo, a continuar a história da Branca de Neve depois que ela se casou com o príncipe); ou a imaginar a história em que tudo acontece ao contrário (as características de personalidade dos personagens são contrárias as da história original e os fatos ocorreram de uma forma um pouquinho diferente...); ou a criar uma Salada de Histórias, misturando tudo de forma engraçada e original. E ainda, no exercício "Semelhanças e Diferenças", pede-se para o aluno listar o maior número possível de semelhanças e diferenças que pode haver entre: o lobo mau e o patinho feio; o jornal nacional e a novela das oito; o automóvel e a carroça; o repórter e o médico.

Outra forma de trabalhar a criatividade é estimular traços de personalidade compatíveis com o pensamento criativo, isto é, favorecer oportunidades dos alunos praticarem e adquirirem confiança, independência, intuiçáo, alta motivação; mostrar disponibilidade para correr riscos calculados e ter uma mente aberta a novas ideias (ALENCAR, 2007; DAVIS, 2006; RENZULLI, 1986a).

(4) Indicaçóes Especiais: Dada a flexibilidade do Modelo das Portas Giratórias, o Pool de Talentos foi organizado de forma a permitir, também, a entrada de alunos que tenham se destacado em anos anteriores, mas que, por problemas emocionais, pessoais, ou motivacionais, possam estar, no momento, desenvolvendo um padrão de 
baixo rendimento escolar. Há que se lembrar que um aluno pode estar demonstrando pouco interesse nas disciplinas escolares por razóes diversas, como pelo fracasso da própria escola em prover ambientes de aprendizagem apropriados para as crianças em seus diferentes estilos de aprendizagem (SEELEY, 1993); pela dificuldade do ambiente escolar em aceitar o pensamento divergente e inconformismo (BUTLER-POR, 1993); ou mesmo pela falta de identificação do aluno com professores que não encorajam suas fontes de interesse (WHITMORE, 1986).

Esta forma de indicação para o programa é interessante, pois, às vezes, um professor consegue obter, em algum momento da vida escolar do aluno, um alto desempenho em matérias escolares específicas; no entanto, se tais oportunidades não se repetirem em anos posteriores, o aluno pode vir a não ter outra chance de demonstrar as suas habilidades ou interesses, perdendo uma valiosa oportunidade de trabalhar com mais profundidade suas áreas fortes. Assim, é recomendável que a equipe diagnóstica busque informaçóes sobre o aluno com seus professores de anos anteriores, sempre que isso for possível.

(5) Indicaçáo por meio da Informaçáo da Ação: Este tipo de nomeação para a participação no programa destaca o papel preponderante da motivaçáo no processo de aprendizagem. No Modelo dos Três Anéis, conforme já pontuado, a habilidade superior se manifesta quando há uma confluência da habilidade em uma área específica com a criatividade e com o envolvimento com a tarefa (RENZULLI, 1986b). Sendo assim, e como a formação do Pool de Talentos é um processo dinâmico que pode ocorrer a qualquer momento do ano escolar, o professor pode também designar para o atendimento algum aluno que tenha demonstrado um interesse incomum por alguma matéria, disciplina ou tópico que esteja sendo estudado naquele momento. Renzulli e Reis criaram um instrumento informal, em formato de uma lâmpada (ver Fig. 5), cunhado de "Mensagem de Informação da Ação" (Action Information Message), no qual o professor anota as açóes e atitudes do aluno frente ao tópico de interesse, ressaltando as atividades em que tenha demonstrado criatividade, alta motivação ou envolvimento com a tarefa realizada na sala de aula (RENZULLI, 1994; RENZULLI \& REIS, 1997). O professor anota também idéias e sugestóes para futuras intervençóes na área, que poderiam ajudar o aluno a desenvolver e aprofundar seu interesse específico, e as compartilha com o coordenador da área de superdotação da sua escola. Este, por sua vez, utiliza o instrumento e as informaçóes obtidas com o professor como uma fonte suplementar de dados sobre o aluno, e os analisa a luz dos seus interesses e áreas fortes, incluindo-o como possível candidato ao Pool de Talentos. 


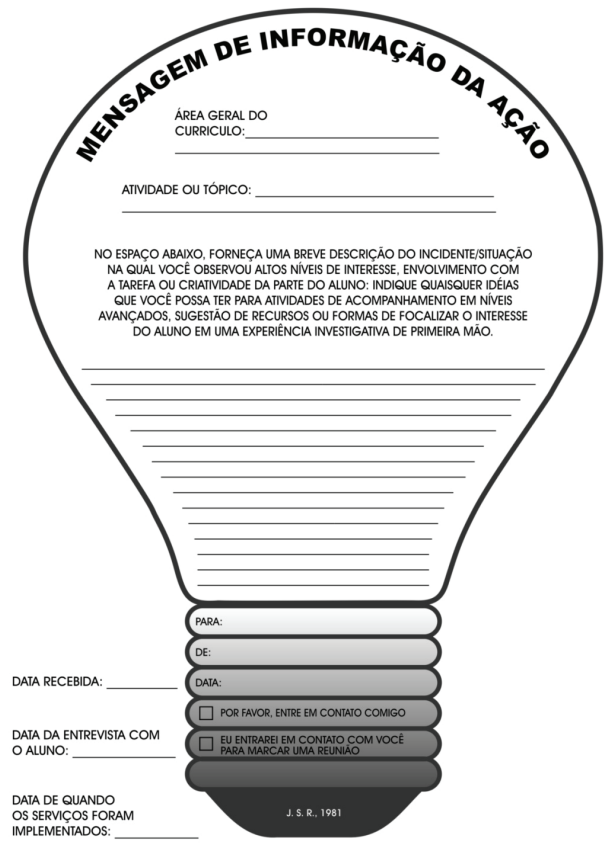

Figura 5: Mensagem de Informação da Açấo (Action Information Message). (RENZULLI \& REIS, 1997). Instrumento traduzido e adaptado por Virgolim (2007b). Reproduzida com a autorização dos autores.

Alunos motivados geralmente demonstram interesse por meio de uma série de comportamentos, tais como: fazer grande número de perguntas; engajar-se em profundas discussōes sobre um determinado tópico; buscar adultos com conhecimento na área para satisfazer seus interesses ou curiosidade; dedicar grande parte do tempo livre no estudo ou no desempenho de atividades relacionadas a este interesse, por sua própria vontade, e, às vezes, até compulsivamente; buscar atividades extracurriculares relacionadas à área, nas quais demonstra mais interesse do que em suas atividades escolares regulares; demonstrar alto interesse em explorar e criar dentro de um determinado tópico (DAVIS, 1997; RENZULLI \& REIS, 1997). Assim, o professor atento aos interesses dos alunos pode detectar mais prontamente o maior envolvimento do estudante com uma determinada tarefa, o que pode ser o aspecto que vai levá-lo a desenvolver sua criatividade e habilidades específicas na área de interesse.

(6) Notificaçáo e Orientaçáo aos Pais: Ao final da formação do Pool de Talentos, os pais são notificados e convidados a comparecerem à primeira reunião com o coordenador da área de superdotação, em que o programa é apresentado e discutido. Os pais são informados das sessóes de orientação (para pais e para os alunos, quando houver) e da possibilidade de marcarem reuniôes individuais por solicitaçáo deles ou dos professores. Explica-se, aos pais, que os alunos, neste modelo de atendimento, não são rotulados como "superdotados", mas aprendem que o desenvolvimento de 
comportamentos criativos e produtivos é, ao mesmo tempo, meta do programa e responsabilidade de cada um. Esta abordagem é importante para impedir a falsa expectativa, tanto nos pais, quanto no aluno, de que este irá fazer parte do programa quando se começam a aplicar os instrumentos de avaliação e diagnóstico. Renzulli recomenda fortemente que tanto o aluno quanto os pais sejam corretamente informados do que se espera dele no programa de altas habilidades (RENZULLI \& REIS, 1986, 1997; BURNS, 1990), o que vai desde a concepção de superdotação, a investigação dos interesses, aptidóes e estilos de aprendizagem, até o desenvolvimento de um projeto do Tipo III (ou seja, a oportunidade de aplicar seus interesses, conhecimentos, idéias criativas e motivação em um problema ou área de estudo de sua escolha).

\section{A questão da avaliação}

$\mathrm{O}$ aluno deve continuar a frequentar a sala de recursos até que seu projeto seja completado; depois deste tempo, ele pode ou náo continuar no atendimento, dependendo basicamente de duas condiçôes: (a) de continuar demonstrando alto nível de envolvimento e criatividade para continuar a desenvolver pesquisas mais avançadas na área de interesse; (b) da avaliação da equipe diagnóstica e dos professores envolvidos, que deve apontar para a continuidade dos ganhos para o aluno de sua permanência na sala de recursos. No entanto, os autores do Modelo deixam claro que este é um processo flexível, que busca a dar acesso a mais alunos ao programa (espera-se que em torno de 15 a 20\% dos alunos de uma escola possam ser identificados como tendo altas habilidades em alguma área), e que deve estar em consonância com as necessidades percebidas pelos professores na sala de aula regular (RENZULLI, REIS \& SMITH, 1981). Assim, torna-se fundamental que o programa para altas habilidades/superdotação faça uma avaliaçáo sistemática dos alunos, que permita observar e registrar o progresso do aluno com relação as suas aptidôes e interesses; o desenvolvimento das suas habilidades no decorrer do programa; e, principalmente, se as metas que foram propostas para aquele período ou etapa foram atingidas parcial ou completamente. Esta documentação sistemática é que viabilizará futuras decisóes sobre o aluno no programa, como por exemplo, o treinamento cognitivo e afetivo que ele precisa receber para que suas potencialidades sejam elevadas ao grau máximo.

A próxima sessão tratará das formas utilizadas no Modelo para se documentar as habilidades e áreas fortes dos estudantes, focalizando seus interesses, aptidôes e estilos de aprendizagem.

\section{Verificação de interesses, aptidões e estilos de aprendizagem}

O Modelo de Enriquecimento Escolar focaliza duas formas principais de se obter informaçóes sobre os interesses, aptidóes e estilos de aprendizagem dos estudantes. Uma delas é denominada "Informação sobre o Status", ou seja, os talentos, áreas fortes e interesses que esses alunos já possuem quando de sua entrada para o programa (talento manifesto, de acordo com a Fig. 2). A segunda forma é a "Informação da Ação" (veja a Fig. 5), ou seja, os talentos, áreas fortes e interesses que podem vir a 
surgir, tanto durante as atividades de enriquecimento em um programa para as altas habilidades, quanto na sala de aula regular, quando o aluno expressa seus interesses com relação ao material que está sendo apresentado no currículo.

O levantamento de interesses, habilidades e dos estilos de aprendizagem do aluno também podem ser apreendidos de forma sistemática através de outro instrumento, de simples adaptação e aplicação, o Portfólio do Talento Total (RENZULLI \& REIS, 1997; PURCELL \& RENZULLI, 1998). Este instrumento pode ser utilizado para se obter informação sobre as áreas fortes dos alunos, nível de desempenho em áreas de aptidão, interesses gerais e específicos do estudante no contexto escolar e fora dele, além das formas individuais de aprender e mostrar o que aprendeu.

Os autores recomendam que cada escola ou programa personalize o Portfólio, de forma que ele reflita, da melhor forma possível, as melhores informaçóes que queremos saber de nossos alunos, tais como: Quais são seus interesses? Quais idéias os motiva? Quais são seus estilos preferenciais de aprender? Com quem eles trabalham melhor? Quais são seus objetivos? Duas questôes guiam o uso deste instrumento: Quais são as melhores coisas que podemos saber sobre cada aluno de nossas escolas? $\mathrm{O}$ que os professores podem fazer para capitalizar sobre os recursos do aluno a partir destas informações?

O Portfólio do Talento Total (PTT) objetiva ajudar os alunos, pais e educadores a: (1) Coletar diferentes tipos de informação que sejam ilustrativas das áreas fortes do estudante e manter essas informaçôes atualizadas com regularidade (a representação de alguns dos maiores indicadores de talento incluídas no portfólio está ilustrada na Fig. 6); (2) Classificar a informação em categorias gerais incluindo habilidades, interesses, estilos preferenciais de aprender, produtos altamente ilustrativos e outros indicadores de talento relacionados; (3) Revisar a informação contida no Portfólio regularmente; (4)Analisar o perfil de talento particular de cada aluno, assim como suas metas educacionais, pessoais e profissionais, e (5) Decidir as opçóes de enriquecimento e aceleração que mais provavelmente ajudarão no desenvolvimento dos talentos e habilidades de cada pessoa. Tais decisóes devem emergir após um processo compartilhado entre pais, alunos e professores (PURCELL \& RENZULLI, 1998, p. $4-5)$.

Informação sobre o Status - A informação sobre o Status se refere ao que já sabemos sobre as áreas fortes do aluno quando investigamos suas habilidades, interesses e estilos de aprender preferenciais. Vamos ver como o Portfólio do Talento Total trabalha cada uma destas áreas (PURCELL \& RENZULLI, 1998).

(1) Habilidades: as habilidades se referem à aptidão ou talento natural do aluno com relação a certas áreas particulares do conteúdo. Tradicionalmente, pensamos nas quatro grandes áreas do currículo - Linguagem/Literatura, Estudos Sociais, Matemática e Ciências. Contudo, as áreas fortes de um estudante podem ser evidenciadas em áreas menos tradicionais, como artes visuais e cênicas, dança, esportes, filmagem, fotografia, computação ou qualquer outra área do conhecimento humano. No PTT, as áreas que demonstram maiores habilidades podem ser documentadas por meio das notas (parciais ou finais) do aluno em testes escolares ou em testes padronizados de aptidáo; ou por meio de observaçóes sistemáticas dos professores 


\begin{tabular}{|c|c|c|c|c|c|c|c|c|c|c|c|c|c|}
\hline 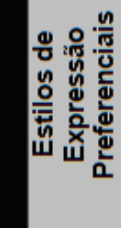 & 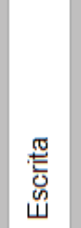 & 징 & 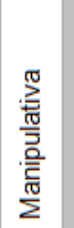 & 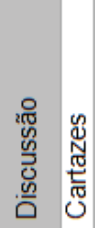 & 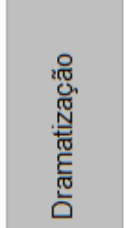 & $\begin{array}{l}\frac{\pi}{0} \\
\frac{.0}{W 0} \\
\frac{.0}{5}\end{array}$ & 荧 & $\begin{array}{l}\overline{\frac{\pi}{0}} \\
\frac{\overline{0}}{\mathrm{~d}} \\
\overline{\mathrm{c}} \\
0\end{array}$ & 这 & & & & 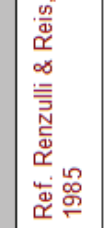 \\
\hline 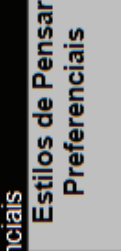 & 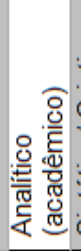 & 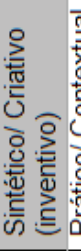 & 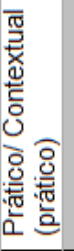 & 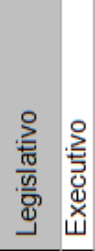 & $\begin{array}{l}\frac{\bar{\pi}}{0} \\
\frac{0}{3} \\
\end{array}$ & & & & & & & & 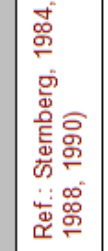 \\
\hline 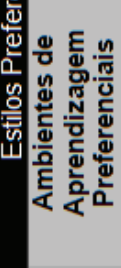 & 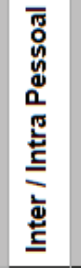 & 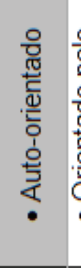 & 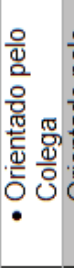 & 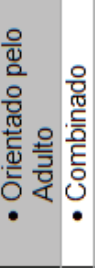 & $\frac{8}{\frac{i}{4}}$ & $\begin{array}{l}E \\
\text { E } \\
\bullet\end{array}$ & 흠 & $\stackrel{N}{\exists}$ & 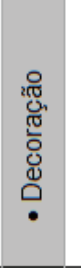 & $\begin{array}{l}\frac{0}{0} \\
\frac{\pi}{0} \\
\frac{0}{\overline{0}} \\
\sum_{0}^{\circ} \\
\text {. }\end{array}$ & $\begin{array}{l}\frac{\pi}{0} \\
0 \\
0 \\
\frac{0}{0} \\
\frac{\pi}{0} \\
\text { ⿳亠丷厂 } \\
\end{array}$ & 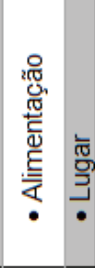 & 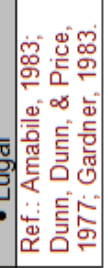 \\
\hline 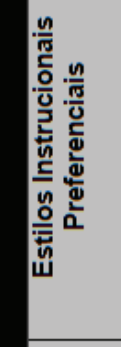 & 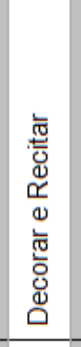 & 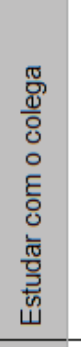 & 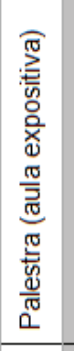 & 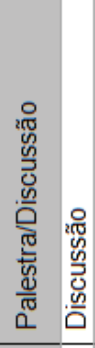 & 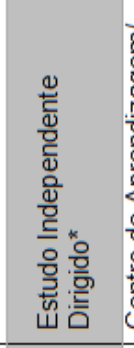 & 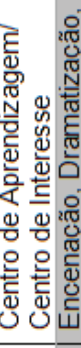 & 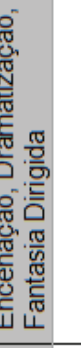 & 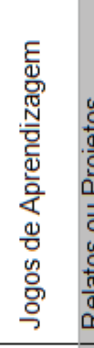 & 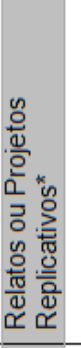 & 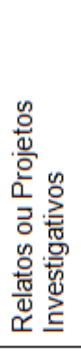 & 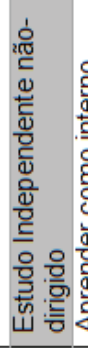 & 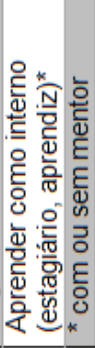 & 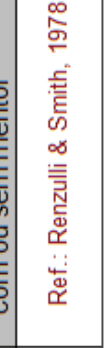 \\
\hline 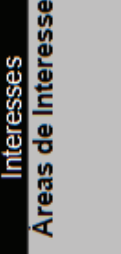 & 告 & 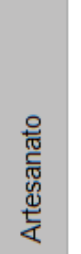 & 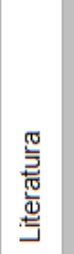 & 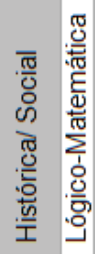 & 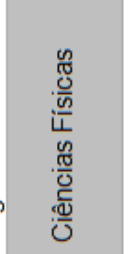 & 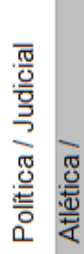 & 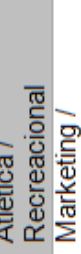 & 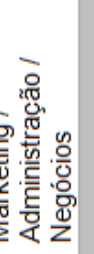 & 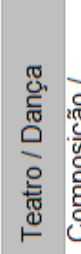 & 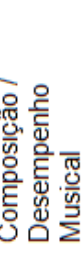 & 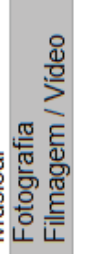 & 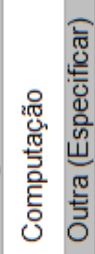 & 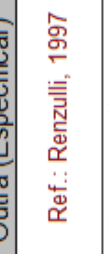 \\
\hline 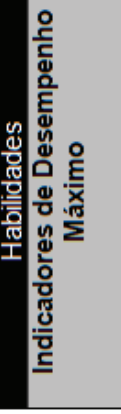 & 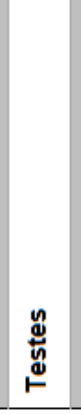 & 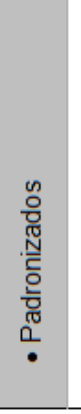 & 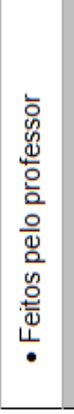 & 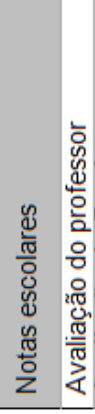 & 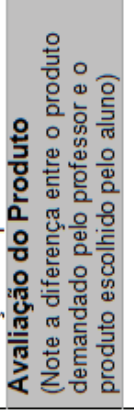 & 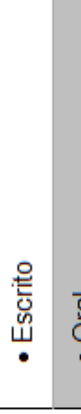 & ? & $\sum^{\frac{\pi}{3}}$ & 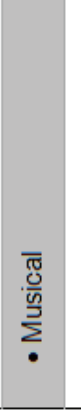 & 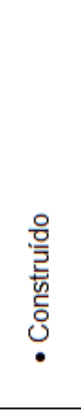 & 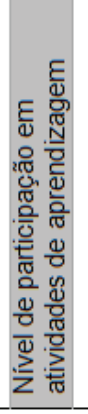 & 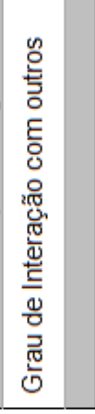 & 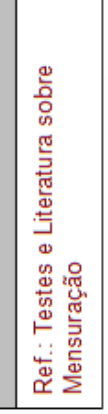 \\
\hline
\end{tabular}

Revista Educação Especial | v. 27 | n. 50 | p. 581-610 | set./dez. 2014 
com relação às áreas mais proeminentes. Outra forma de documentar habilidades é agregar ao portifólio escalas de avaliação de características de altas habilidades, como o SCRBSS, já descrito anteriormente. Vale a pena repetir aqui que o PTT pode e dever ser adaptado para refletir as áreas que a escola considera mais importantes a serem documentadas.

(2) Interesses: a parte primordial do PTT é a questão dos interesses, uma vez que o talento flui naturalmente da área de interesse.

Uma grande diferenciação que se faz entre o ensino regular e o especializado é o fato de que, no ensino regular, em geral o aluno não tem a liberdade de escolher o tópico que quer estudar; de estabelecer o ritmo da sua aprendizagem; de propor seus próprios problemas e determinar a maneira como quer resolvê-los; e de poder fazer escolhas significativas com relação ao currículo. Já no ensino especializado, essa liberdade é parte da metodologia, pois os alunos devem escolher seus tópicos de interesse e ter oportunidade de trabalhar suas áreas fortes (RENZULLI \& REIS, 1997; PURCELL \& RENZULLI, 1998). Embora os autores deixem claro que a educaçáo não pode estar inteiramente centrada na área de interesse de um aluno, salientam a crença de que uma porção significativa das oportunidades de aprendizagem em sala de aula pode ser baseada na grande variedade de interesses do alunado. Além disso, focalizar parte do ensino, onde for possível, em áreas de alto interesse do aluno encoraja a produtividade criativa real. Para isso, é necessário que o professor tenha em mãos instrumentos que o permitam, periodicamente, delinear os interesses do estudante, tanto gerais quanto específicos, e refinar estes interesses em tópicos suficientemente claros que possam ser investigados e pesquisados.

Outro instrumento de grande utilidade é o Levantamento de Interesses ou Interest-a-Lyser ${ }^{2}$ (RENZULLI, 1977, 1997), palavra cunhada pelo autor para designar a ação de fazer aflorar interesses em áreas gerais e específicas. Além da versão adulta, Renzulli desenvolveu versóes para crianças do Ensino Infantil e do Fundamental, e outra para jovens do Ensino Médio, além de outra, específica para a área de artes.

O Levantamento de Interesses (RENZULLI, 1997) para crianças do Ensino Fundamental consiste em um questionário de 30 itens, com o propósito de ajudar o aluno a explorar suas áreas individuais de interesse. Exemplo de algumas atividades deste instrumento:

- Imagine que uma máquina do tempo tenha sido inventada para permitir que pessoas famosas do passado viajassem através do tempo. Se você pudesse convidar algumas dessas pessoas para visitar sua escola, quem você convidaria?

- Imagine que você será levado para uma estação espacial no seu próximo ano escolar. Você terá permissão para levar algumas coisas pessoais para ajudá-lo a passar seu tempo livre (por exemplo, livros, jogos, filmes, passatempos, projetos). Faça uma lista das coisas que você levaria.

- Imagine que você pudesse passar uma semana acompanhando qualquer pessoa da sua escolha para investigar um pouco mais a profissão que você gostaria de ter no futuro. Liste as profissóes das pessoas que você selecionaria. 
Em suas várias versões, o Levantamento de Interesses permite uma maior comunicaçáo entre professores e alunos e entre grupos homogêneos de alunos com interesses similares e que talvez gostassem de desenvolver esses tópicos em níveis mais avançados. A tarefa posterior do professor é afunilar estes interesses, buscando tópicos específicos no campo de interesse que possam ser pesquisados em profundidade. É bom voltar a lembrar que os interesses de crianças e mesmo dos jovens mudam com o tempo, desta forma, o levantamento de interesses e sua documentação em instrumentos como o PTT deve ser feito periodicamente. O professor deve também conversar com os alunos sobre seus interesses, de forma a validar as informaçóes obtidas e esclarecer as particularidades que possam surgir das respostas escritas.

(3) Estilo de Aprendizagem: cada aluno demonstra uma forma específica com que gostaria de aprender ou de ser ensinado em sala de aula. Neste sentido, enquanto alguns alunos preferem estudar ouvindo música, ou um estilo específico de música ,outros preferem o mais completo silêncio, alguns gostam de estudar deitados, e outros sentados à escrivaninha, e alguns gostam de ouvir palestras e uma aula teórica, enquanto outros preferem aprender através de jogos. Um dos instrumentos desenvolvidos para se ter acesso aos diferentes estilos de aprendizagem dentro de sala de aula é o Inventário de Estilos de Aprendizagem ${ }^{3}$ (RENZULLI \& SMITH, 1978), que tem como objetivo ajudar o professor a planejar suas aulas levando em conta os diferentes estilos de aprendizagem de seus alunos. $\mathrm{O}$ instrumento consiste em uma série de itens que descrevem vários tipos de atividades de aprendizagem, e ao quanto os alunos gostariam, em uma escala de 0 (detesto) a 4 (adoro), de participar destas atividades. Exemplos de algumas atividades deste instrumento:

- Ter a ajuda de um amigo para aprender uma matéria difícil de entender.

- Trabalhar com outros alunos em um projeto, com pouca ajuda do professor.

- Tomar notas à medida que o professor fala para a classe.

- Aprender sobre profissóes representando o papel de um chefe e entrevistar outros alunos que estáo representando o papel de candidatos ao trabalho.

- Trabalhar individualmente para obter informação sobre um tópico de seu interesse.

Os itens, neste instrumento, permitem identificar nove estratégias instrucionais mais preferidas pelos alunos ao entrar em contato com o currículo ou demonstrar seus interesses em sala de aula. São elas:

(1) Palestra (apresentação oral de informação a um grande número de alunos); alunos com alta pontuação nesta dimensão respondem favoravelmente a itens como "Outros alunos que sabem bastante um tópico apresentam suas idéias para a classe"; "Ouvir o professor dar informaçôes novas".

(2) Discussão (interação professor/alunos para promover o desenvolvimento do pensamento lógico por meio da discussão de fatos); alunos com alta pontuação nesta dimensão escolheram itens como: "Discutir em classe um assunto sugerido pelo professor"; "Compartilhar suas idéias com outros alunos durante uma discussão de classe sobre algum tópico". 
(3) Ensino pelo colega (interação entre um aluno que domina uma área do conhecimento e um ou mais colegas com dificuldades em entender um conceito ou tópico); escolha de itens como: "Ter a ajuda de um amigo para aprender uma matéria difícil de entender; "Ter um colega da mesma série para revisar com você a matéria da prova".

(4) Jogos pedagógicos (atividades percebidas como agradáveis para os estudantes, centradas em conteúdos que os professores querem transmitir aos alunos); itens como: "Usar um jogo de tabuleiro para praticar uma de suas matérias escolares"; "Participar de uma competição para ajudar seu time a responder corretamente a maioria das perguntas sobre um tópico que você está estudando em classe”.

(5) Dramatização (simulaçóes em pequenos grupos ou com a sala toda para aprendizagem de conteúdo e habilidades; são simulações baseadas em problemas reais e exigem que o aluno tome decisôes que irão afetar o próximo movimento dos outros jogadores); alunos com alta pontuação nesta dimensão escolheram itens como: "Aprender sobre um evento tal como a Independência, dramatizando em classe"; "Aprender sobre o processo de eleição representando o papel de um membro de um partido que compete com outro partido para ganhar votos para seu candidato".

(6) Estudos independentes (praticados por pequenos grupos ou de forma independente pelo aluno que desenvolve um tema de interesse); alunos escolheram itens como: "Trabalhar independentemente em um projeto que você mesmo escolheu"; "Estudar por conta própria para aprender coisas novas".

(7) Projetos (atividades escolares desenvolvidas pelo aluno de acordo com seus interesses, pressupondo trabalho de pesquisa e apresentaçáo para o grupo de pares) itens como: "Ir com um grupo à biblioteca para procurar informaçōes"; "Trabalhar com outros alunos em um projeto, com pouca ajuda do professor";

(8) Atividades de decorar e recitar (atividades em que o estudante demonstra retenção e memorização do conhecimento ao responder questóes colocadas pelo professor); alunos bem pontuados nesta dimensão escolheram itens como: "O professor faz perguntas à classe sobre a matéria que foi dada para ser estudada"; "Dar respostas em voz alta a perguntas feitas pelo professor"; "Participar de exercícios em sala de aula nos quais o professor pede informação específica para cada aluno da classe”.

(9) Instrução programada (programa de aprendizagem estruturada em que alunos trabalham independentemente, respondendo um conjunto de questóes pré-programadas pelo professor, cujas respostas são apresentadas após cada questão); itens como: "Responder por escrito a perguntas sobre uma matéria que você acabou de ler"; "Trabalhar em tarefas nas quais você completa a palavra que falta para completar uma frase"; "Fazer tarefas que você pode descobrir depois de cada pergunta se sua resposta está correta ou não".

Da mesma forma, o professor é solicitado a responder ao mesmo instrumento, mas apontando a freqüência com que as atividades ocorrem em sala de aula, e suas 
respostas são comparadas as dos alunos. Assim, o perfil que resulta deste procedimento permite comparar as preferências de aprendizagem dos alunos com o estilo de ensinar do professor, dando uma visão mais acurada do que ocorre na sala de aula. Pesquisas têm demonstrado que a combinação entre os estilos de aprender dos alunos e os de ensinar do professor não apenas produzem uma melhoria da aprendizagem do aluno, mas também uma atitude mais positiva com relação à escola (RENZULLI \& REIS, 1986; RENZULLI \& SMITH, 1978).

Um interessante instrumento desenvolvido de forma similar para documentar os interesses, habilidades e estilos de aprendizagem do aluno, baseado no Portfólio de Talento Total é Minhas Digitais do Aprendizado (SCHADER \& ZHOU, 2006). Segundo as autoras, trata-se de uma ferramenta educacional para destacar a combinação única de interesses, habilidades, experiências e preferências de aprendizado e ajudar o aluno a descobrir suas próprias digitais do aprendizado. Dirigindo-se ao aluno, elas enfatizam que "assim como duas impressões digitais não são idênticas, você irá perceber que duas digitais do aprendizado também não são. Isso é o que contribui em tornar você alguém muito especial" (p.1). O instrumento agrega as funcionalidades de um questionário com perguntas gerais, seguidas de opçôes a serem marcadas em escala do tipo Lickert. Abre também espaços, ao final de cada sessão, para observaçóes subjetivas e relatos do aluno.

Assim, Minhas Digitais do Aprendizado focaliza três áreas, a saber (COUTINHO, 2009):

(1) Áreas fortes na escola e tópicos de interesses, subdividido em três áreas: (a) áreas fortes na escola (o aluno é convidado a marcar na escala as disciplinas escolares que ele gosta e aquelas nas quais ele se destaca); (b) áreas especiais para explorar (o aluno descreve as tarefas nas quais ele tem muito interesse e dedica grande parte do seu tempo); e (c) interesses gerais, em que ele assinala as áreas que o interessam mais e aquelas nas quais ele dedica mais tempo.

(2) Preferências de Estilo de Aprendizagem, com quatro subdivisóes: (a) formas de aprender (o aluno assinala as formas preferenciais de aprender de acordo com os estilos de ensinar do professor); (b) formas de pensar (o aluno evidencia suas formas favoritas de gravar novas informaçóes); (c) melhores condiçóes para aprender (o aluno assinala as condiçôes ambientais mais favoráveis a sua aprendizagem), e (d) formas de mostrar o que aprendi (o aluno demonstra seu estilo preferencial de mostrar a uma audiência o que aprendeu).

(3) Atividades e Experiências, em que são apresentadas cinco proposições: (a) atividades fora de sala (o aluno descreve as atividades realizadas após o período de aulas ou fora do ambiente escolar regular); (b) experiências em família (o aluno relata atividades realizadas junto a seus familiares); (c) o que eu faço em casa (o aluno relata as atividades que ele gosta de realizar em casa); (d) hobbies e coleçóes (o estudante descreve as atividades que gosta de realizar como diversão ou o que gosta de colecionar), e (e) motivação; neste último item quatro frases incompletas são apresentadas 
com relação à motivação para aprender: "eu gosto de aprender porque ...", "eu quero aprender porque ...", "aprender é mais fácil para mim quando ...", e "aprender é mais difícil para mim quando ...”.

\section{Opções educacionais oferecidas aos alunos do Pool de Talentos}

Com tantas e variadas informaçóes coletadas sobre os interesses, aptidôes e estilos de aprendizagem dos alunos, o professor tem agora uma excelente visão sobre cada um de seus estudantes; torna-se necessário, então, "capitalizar" sobre estas informaçôes, de forma a poder fornecer a eles opçóes educacionais bem planejadas que possam levar ao adequado desenvolvimento de suas potencialidades latentes, emergentes e manifestas.

Ajudar o aluno a traçar os objetivos ou metas a serem alcançados no programa seria a primeira tarefa. Metas devem ser realistas, desafiadoras, específicas, com início e fim bem estabelecidos. O professor deve ajudar o aluno a estabelecer suas próprias metas, dando exemplos que possam ser seguidos, tendo suas áreas de interesse como ponto de partida. Tais metas podem ser desenvolvidas na escola ou no ambiente externo, como família, clube, comunidade (PURCELL; RENZULLI, 1998).

O segundo passo em um bom programa para alunos com altas habilidades, seria suprir e complementar suas necessidades específicas, possibilitando a ampliaçáo do seu desenvolvimento pessoal e criando oportunidades para que eles encontrem desafios escolares compatíveis com suas habilidades. Ressaltam Sabatella e Cupertino (2007) que o aluno com altas habilidades/superdotação, por seus interesses variados e habilidades diversas, tem necessidade de envolvimento em atividades que favoreçam a produção criativa. Elas complementam ainda que os alunos superdotados:

$$
\begin{aligned}
& \text {... precisam encontrar desafios que girem em torno de temas impor- } \\
& \text { tantes e úteis, enriquecendo seu conhecimento e oferecendo opor- } \\
& \text { tunidades para alargar seus horizontes pessoais, projetar objetivos } \\
& \text { maiores e desenvolver senso de responsabilidade e independência } \\
& \text { intelectual. Necessitam também encontrar metodologia adequada } \\
& \text { à sua rapidez de raciocínio e grande capacidade de abstraçáa, em } \\
& \text { um processo dinâmico de aprendizagem. (p. 70) }
\end{aligned}
$$

Para que estes objetivos sejam atingidos, as autoras lembram que os alunos com altas habilidades beneficiam-se tanto da interação com os pares da mesma idade quanto com os pares intelectuais. Sendo assim, programas para esta população devem criar flexibilidade compatível com as adaptações necessárias a uma educação que atenda ao perfil heterogêneo deste alunado.

Vários serviços educacionais poderão ser oferecidos aos alunos identificados para o Pool de Talentos ainda dentro do ensino regular. Dentre os mais indicados está a compactaçáo do currículo, que permite aos alunos com habilidades intelectuais superiores prosseguir de forma mais rápida com o conteúdo que já foi dominado, eliminando a rotina de passar por exercícios repetitivos desnecessariamente. $\mathrm{O}$ recurso da compactação do currículo torna mais desafiador o ambiente de aprendizagem, 
dando ao aluno oportunidade de aproveitar melhor seu tempo para o desenvolvimento de atividades de enriquecimento e abrindo espaço para a aceleração escolar (REIS, BURNS; RENZULLI, 1992; STARKO, 1986).

Dois procedimentos são essenciais para a compactação do currículo: (1) um cuidadoso diagnóstico da situação, e (2) completo conhecimento do conteúdo e dos objetivos da unidade de instrução. O professor deve identificar a área do currículo que o aluno já dominou e suas áreas fortes, geralmente observadas quando o aluno termina rapidamente uma tarefa com pouco ou com nenhum erro, e quando demonstra insatisfação, tédio ou desânimo com o ensino, desperdiçando o seu tempo em sala de aula para sonhar acordado ou fazer bagunça. Em seguida, o professor deve aplicar atividades ou pré-testes para assegurar se o aluno tem completo domínio do tema ou conteúdo, e se atende aos objetivos daquela unidade. $\mathrm{Na}$ maioria dos casos, as provas e avaliaçóes utilizadas ao término do bimestre ou semestre servem como pré-teste. Uma vez documentada a área em que o aluno já domina, o professor indica as atividades que podem ser eliminadas do currículo ou aceleradas para se adaptar ao ritmo próprio do aluno. E, por fim, o professor explora as diversas formas de aceleração ou enriquecimento que ele poderia providenciar ainda na sala de aula regular. Por exemplo, se várias unidades curriculares de matemática foram compactadas, o professor deve decidir se o aluno pode ser acelerado para outra série ou se poderá ser beneficiado por um aprofundamento do conteúdo na matéria, ou mesmo se deve dedicar o tempo extra a outra disciplina ou tópico de interesse. A filosofia do programa, os recursos viabilizados, e consideraçóes práticas, tais como restriçóes da escola à aceleraçáo, e a maturidade do aluno para assumir tarefas específicas de outra série devem subsidiar tais decisôes.

É importante notar que os alunos devem participar destas decisóes e entender que, ao dar o melhor de si em uma disciplina, poderá ter mais tempo para trabalhar em outro tópico do seu interesse. Neste sentido, alunos que tradicionalmente demonstram desinteresse com o ensino, tiram notas baixas ou deixam de assistir as aulas, passam a ter maior interesse em dominar o conteúdo e a demonstrar o que sabem.

Ainda em concordância com o Modelo de Enriquecimento Escolar de Renzulli, Sabatella e Cupertino (2007), discutem três importantes modalidades de intervenção nos programas para superdotados: agrupamento, aceleraçáo e enriquecimento.

Os sistemas de agrupamento dos alunos podem se dar em centros específicos, em escolas ou classes especiais, ou em pequenos grupos diferenciados dentro na sala de aula regular. A estratégia de agrupamento gera maior possibilidade de aprofundamento dos temas de acordo com o que é interessante e apropriado para cada indivíduo, além colaboraçáo com o conjunto de seus pares. No entanto, é necessário que os professores estejam atentos para proporcionar oportunidade aos alunos para uma convivência escolar com outros alunos de diferentes habilidades, e que reconheçam as amplas diferenças individuais do grupo, incluindo, sempre, alguma instruçáo individualizada. 
A aceleraçáo, que no Brasil já está prevista na nova LDBEN, significa cumprir o programa escolar em menor tempo, o que pode se dar por admissáo precoce na escola ou por permitir que o aluno realize seus estudos em tempo inferior ao previsto. O aluno que já domina os conteúdos da série em que se encontra pode também ir para uma série mais adiantada. Para se indicar a aceleração, no entanto, o profissional deve avaliar aspectos do aluno, como o conhecimento acadêmico e a capacidade intelectual, seu desenvolvimento físico, emocional e a maturidade, e, ainda, as condiçôes da escola e receptividade do professor com relaçáo ao processo.

O enriquecimento pressupóe o fornecimento de uma variedade de experiências de aprendizagem enriquecedoras que estimulem o potencial dos alunos e que normalmente não são apresentadas no currículo regular. De acordo com Freeman e Guenther (2000), as atividades de enriquecimento objetivam tornar o processo educativo o mais individualizado possível, sem perder de vista parâmetros como as exigências do sistema de ensino e as necessidades sócio-afetivas do aluno. O MEC sugere alternativas de enriquecimento que pode se dar na própria sala de aula, com programas curriculares enriquecidos; em grupos com conteúdos paralelos ao currículo comum; em grupos especiais, com atividades diferenciadas em alguns aspectos da programaçáo normal; em salas de recurso, em horário contrário ao da classe regular, e por meio do ensino com professor itinerante (BRASIL, 1995).

\section{Modelo Triádico de Enriquecimento}

Renzulli e Reis (1997) e Burns (1990) sugerem encorajar os estudantes a participar de atividades investigativas que resultarão no desenvolvimento de um produto criativo. Para estimular os alunos a desenvolverem habilidades que os permitam ser produtores de conhecimento, mais do que simplesmente consumidores, estes autoresimplantaram o Modelo Triádico de Enriquecimento, no qual três tipos de enriquecimento são planejados para os contextos tanto do ensino regular quanto do especializado.

O Enriquecimento Escolar do Tipo I se inicia na sala de aula regular e implica em atividades destinadas a todos os estudantes da escola. Seu principal objetivo é o de expor os alunos a uma grande variedade de disciplinas, tópicos, pessoas, lugares, eventos, ocupaçóes e passatempos que normalmente não fazem parte do currículo da escola regular. Esta abordagem tem três importantes objetivos: (1) Dar oportunidade a todos os alunos de participar de alguma experiência de enriquecimento curricular que seja de seu real interesse; (2) enriquecer a vida dos estudantes através de experiências que usualmente não fazem parte do currículo da escola regular, e (3) estimular novos interesses que possam levar o aluno a aprofundá-los em atividades criativas e produtivas posteriores (Tipo III).

O Enriquecimento Escolar do Tipo II também pode ser aplicado nos contextos de sala de aula regular e de recursos; e consiste de técnicas, materiais instrucionais e métodos designados a três grandes áreas, para se promover: (a) o desenvolvimento dos processos de pensamento de nível superior; (b) habilidades específicas de como conduzir pesquisas e utilizar referências, e (c) processos relacionados ao desenvolvi- 
mento pessoal, afetivo e social do aluno. As atividades de enriquecimento de Tipo II têm como objetivo: (1) desenvolver nos alunos as habilidades gerais de pensamento crítico, resolução de problemas e pensamento criativo; (2) desenvolver os processos afetivos, sociais e morais, tais como sentir, apreciar, valorizar, respeitar; (3) desenvolver uma grande variedade de aprendizagens específicas de "como fazer", tais como tomar notas, entrevistar, classificar e analisar dados, tirar conclusóes etc., necessárias ao processo científico; (4) desenvolver habilidades avançadas para a aprendizagem de materiais de referência, tais como resumos, catálogos, registros, guias, programas de computador, Internet, etc., e (5) desenvolver habilidades de comunicação escrita, oral e visual, a fim de que a produção do aluno tenha maior impacto sobre determinadas audiências.

As atividades de Enriquecimento do Tipo III são planejadas para o aluno que demonstra um grande interesse em estudar com maior profundidade uma área do conhecimento; que esteja pronto para dedicar grande parte do seu tempo para a aquisiçáo de um conteúdo mais avançado, e que queira participar de um processo de treinamento mais complexo, no qual assume o papel de aprendiz em primeira-mão. Assim sendo, entre as metas das atividades de Enriquecimento de Tipo III, destacamse a oportunidade para que o aluno possa: (1) aplicar seus interesses, conhecimentos, idéias criativas e motivação em um problema ou área de estudo de sua escolha; (2) adquirir um conhecimento avançado a respeito do conteúdo e metodologia próprios a uma disciplina, área de expressão artística ou estudos interdisciplinares em particular; (3) desenvolver produtos autênticos, com o objetivo de produzir determinado impacto em uma audiência pré-selecionada; (4) desenvolver habilidades de planejamento, organização, utilização de recursos, gerenciamento de tempo, tomada de decisôes e auto-avaliação, e (5) desenvolver motivação/envolvimento com a tarefa, autoconfiança e sentimentos de realização criativa, e habilidade de interagir efetivamente com outros alunos, professores e pessoas com níveis avançados de interesse e conhecimento em uma área comum de envolvimento.

O grande objetivo, a longo prazo, do Modelo Triádico de Enriquecimento é trabalhar progressivamente as diversas habilidades e potenciais dos alunos, valorizar o trabalho criativo, nutrir o potencial criativo e diminuir barreiras de forma a, no futuro, aumentar o número de adultos criativo-produtivos (REIS; RENZULLI, 2009). Comentam os autores:

Devemos aceitar e celebrar diferenças e entender o valor para o nosso mundo quando às pessoas talentosas são dados tempo, ambiente e encorajamento, financeiro e emocional, para criar. Imagine como seria este mundo sem Beethoven, Pasteur, O'Keefe ou Bernhar$\mathrm{dt}$ ? Agora imagine o que aconteceria se alguns dos mais talentosos criadores de nossa civilização fossem forçados a se conformar e não recebessem nenhum apoio. Se não estivermos conscientes das maneiras de ajudar estes indivíduos a buscar sua produtividade criativa, tanto em idades precoces quanto em períodos posteriores de suas vidas, devemos então considerar o grande romance Americano não escrito, o poema não concebido, a cura não desenvolvida e a 
guerra não evitada. Esta é a razão pela qual temos que continuar nossas exploraçóes no entendimento de como promover a criatividade produtiva tanto nos adultos quanto nas crianças. (p. 196-197)

A literatura na área nos tem alertado sobre a dificuldade de se predizer a continuidade das altas habilidades no futuro, principalmente no que diz respeito ao sucesso profissional e pessoal (GARDNER, 2000; RENZULLI, 2004b; STERNBERG, 1997). No entanto, resultados de pesquisa apontam para o papel crítico dos pais e professores na determinação do nível de excelência obtida posteriormente pelo jovem. Sabemos que cada um de nós tem um importante papel no aperfeiçoamento da sociedade; no entanto, este papel apenas pode ser desenvolvido se fornecermos a todos os alunos as oportunidades, os recursos e o encorajamento necessários para aspirar ao mais alto grau, humanamente possível, de desenvolvimento do talento. Este é o objetivo para o qual vale a pena lutar.

\section{Referências}

ALENCAR, E. M. L. S. O papel da escola na estimulação do talento criativo. In: D. S. FLEITH.; E. M. L. S. ALENCAR (Orgs.). Desenvolvimento de talentos e altas habilidades (p. 151-161). Porto Alegre: Artmed, 2007.

ALENCAR, E. M. L. S.; VIRGOLIM, A. M. R. Dificuldades emocionais e sociais do superdotado. In: E. M. L. S. ALENCAR. Criatividade e educaçáo dos superdotados (p. 174-205). Petrópolis: Vozes. 2001.

AMABILE, T. M. Creativity in context. Boulder, CO: Westview Press, 1996.

BARBOSA, K. M. Implementação dos Núcleos de Atividades de Altas Habilidades/Superdotaçấo - NAAH/S. 2007. Trabalho apresentado no Seminário "A construçáo de Práticas Educacionais para Alunos com Altas Habilidades/Superdotaçáa”. Brasília, MEC/SEESP.

BLOOM, B. S.; SOSNIAK, L. A. Talent development and schooling. Educational Leadership, (39), 86-94, 1982.

BRASIL. Ministério da Educaçáo e do Desporto. Diretrizes gerais para o atendimento educacional aos alunos portadores de altas habilidades: Superdotaçáo e talentos. Brasília, DF: MEC / SEESP, 1995.

BURNS, D. E. Pathways to investigative skills. Instructional lessons for guiding students from problem finding to final product. Mansfield Center, CT: Creative Learning Press, 1990.

BUTLER-POR, N. Underachieving gifted students. In K. A. HELLER, F. J. MÖNKS,; A. H. PASSOW (Orgs.). International handbook of research and development of giftedness and talent (p. 649-668). Oxford: Pergamon Press, 1993.

CHAMORRO-PREMUZI, T. Creative Process (entry). In: B. KERR (Ed.), Encyclopedia of giftedness, creativity, and talent (v. 1, p. 191-193). Washington, DC: SAGE, 2009.

CLARK, B. Growing up gifted: Developing the potential of children at home and at school. New York: Macmillan Publishing Company, 1992.

COUTINHO, P. L. Estilos de aprendizagem do aluno superdotado no Ensino Médio. Trabalho de Conclusão de Curso de Especialização em Educação Inclusiva. Brasília: Universidade de Brasília, 2009.

DAVIS, G. A. Identifying creative students and measuring creativity. In: N. COLANGELO.; G. A. DAVIS (Orgs.). Handbook of gifted education, 2nd ed., p. 269-281. Needham Heights, MA: Allyn and Bacon, 1997.

DAVIS, G. A. Gifted children and gifted education: A handbook for teachers and parents. Scottsdale, AZ: Great Potential Press, 2006.

FELDHUSEN, J. F.; JARWAN, F. A. Identification of gifted and talented youth for educational programs. In: K. A. HELLER, F. J. MÖNKS.; A. H. PASSOW (Eds.), International handbook and development of giftedness and talent (p. 233-250). Oxford: Pergamon Press, 1993.

FREEMAN, J. \& GUENTHER, Z. C. Educando os mais capazes: Idéias e açóes comprovadas. São Paulo: EPU, 2000. 
GALBRAITH, J.; DELISLE, J. The gifted kid's survival guide: A teen handbook. Minneapolis, MN: Free Spirit Publishing, 1996.

GARDNER, H. Inteligência: Um conceito reformulado (Trad. A.C. Silva). Rio de Janeiro: Objetiva, 2000.

GUBBINS, E. J. Revolving Door Identification Model: Characteristics of Talent Pool students. Unpublished doctoral dissertation, University of Connecticut, Storrs, 1982.

GUBBINS, E. J. NRC/GT offers a snapshot of intelligence. The National Research Center on the Gifted and Talented (NRC/GT), 1-2, 2005, winter.

LANDAU, E. A coragem de ser superdotado. São Paulo: CERED, 1990.

NEIHART, M.; REIS, S. M.; ROBINSON, N. M.; MOON, S. M. (Org.). The social and emotional development of gifted children: What do we know? Washington, DC: The National Association for Gifted Children, 2002.

PURCELl, J. H.; RENZUlli, J. S. Total Talent Portfolio. Mansfield Center, CT: Creative Learning Press, 1998.

REIS, S. M.; BURNS, D. E.; RENZULLI, J. S. Curriculum compacting. The complete guide to modifying the regular curriculum for high ability students. Mansfield Center, CT: Creative Learning Press, 1992.

REIS, S. M.,; RENZULLI, J. S. Creative Productivity (entry). In: B. KERR (Ed.), Encyclopedia of giftedness, creativity, and talent, v. 1, p. 194-197. Washington, DC: SAGE, 1977.

REIS, S. M.; RENZULLI, J. S. A case for the broadened conception of giftedness. Phi Delta Kappan, 63 (4), 619-620, 1982.

REIS, S. M.; RENZULLI, J. S. Creative Productivity (entry). In: B. KERR (Ed.), Encyclopedia of giftedness, creativity, and talent, v. 1, p. 194-197. Washington, DC: SAGE, 2009.

RENZULLI, J. S. The Interest-a-Lyser. Mansfield Center, CT: Creative Learning Press, 1977.

RENZULLI, J. S. What makes giftedness? Reexamining a definition. Phi Delta Kappan, 60 (3), 180-184, 1978.

RENZULLI, J. S. The three-ring conception of giftedness: A developmental model for creative productivity. South African Journal of Education, 5 (1), 1-18, 1985.

RENZULLI, J. S. New Directions in Creativity. Mark 1. Mansfield Center, CT: Creative Learning Press, 1986a.

RENZULLI, J. S. The three-ring conception of giftedness: A developmental model for creative productivity. In: J. S. RENZULLI,; S. M. REIS (Eds.), The triad reader (p. 2-19). Mansfield Center, CT: Creative Learning Press, 1986b.

RENZULLI, J. S. Schools for Talent Development: A practical plan for total school improvement. Mansfield Center, CT: Creative Learning Press, 1994.

RENZULLI, J. S. Interest-a-Lyser family of instruments: A manual for teachers. Mansfield Center, CT: Creative Learning Press, 1997.

RENZULLI, J. S. Introduction to identification of students for gifted and talented programs. In: S. M. REIS (Org. Serie) \& J. S. RENZULLI (Org. Vol.), Essential Reading in Gifted Education: Identification of students for gifted and talented programs (Vol. 2., p. xxiii-xxxiv). Thousand Oaks, CA: Corwin Press \& The National Association for Gifted Children. 2004a.

RENZULLI, J. S. Myth: The gifted constitutes 3-5\% of the population. Dear Mr. and Mrs. Copernicus: We regret to inform you... In: S. M. REIS (Org. Serie) \& J. S. RENZULLI (Org. Vol.), Essential Reading in Gifted Education: Identification of students for gifted and talented programs, Vol. 2., p. 63-70. Thousand Oaks, CA: Corwin Press \& The National Association for Gifted Children. 2004b.

RENZULLI, J. S. The Three-Ring conception of giftedness. A developmental model for promoting creative productivity. In: R. J. STERNBERG \& J. E. DAVIDSON (Eds.), Conceptions of giftedness (2nd ed., pp. 246-279). New York: Cambridge University Press. 2005.

RENZULLI, J. S., HARTMAN, R. K., \& CALLAHAN, C. M. Teacher identification of superior students. Exceptional Children, 38, 211-214. 1971. 
RENZULLI, J. S.; REIS, S. M. The Enrichment Triad/ Revolving Door Model: A schoolwide plan for the development of creative productivity. In: J. S. RENZULLI (Org.). Systems and models for developing programs for the gifted and talented, p. 216-266. Mansfield Center, CT: Creative Learning Press. 1986.

RENZULLI, J. S.; REIS, S. M. The Schoolwide Enrichment Model: A how-to guide for educational excellence (2nded.). Mansfield Center, CT: Creative Learning Press, 1997.

RENZULLI, J. S.; REIS, S. M. The schoolwide enrichment model. In: K. A. HELLER, F. J. MÖNKS, R.J. STERNBERG; R. F. SUBOTNIK (Eds.), International handbook of giftedness and talent, 2nd ed., p. 367382. Oxford: Elsevier Science. 2000.

RENZULLI, J. S.; REIS, S. M.; SMITH, L. H. The Revolving Door Identification Model. Mansfield Center, CT: Creative Learning Press, 1981.

RENZULLI, J. S.; SMITH, L. H. The Learning Styles Inventory: A measure of student preference for instructional techniques. Mansfield Center, CT: Creative Learning Press, 1978.

RENZULLI, J. S.; SMITH, L. H.; WHITE, A. J.; CALLAHAN, C. M.; HARTMAN, R. K. Scales for Rating the Behavioral Characteristics of Superior Students. Manual. Mansfield Center, CT: Creative Learning Press, 1976.

RENZULLI, J. S.; SMITH, L. H.; WHITE, A. J.; CALLAHAN, C. M.; HARTMAN, R. K.; WESTBERG, K. L.(2002). Scales for rating the behavioral characteristics of superior students (Rev. ed.). Mansfield Center, CT: Creative Learning Press, 2002.

RUNCO. Creativity, definition (entry). In: B. KERR (Ed.), Encyclopedia of giftedness, creativity, and talent (v. 1, p. 200-201). Washington, DC: SAGE, 2009.

SABATELLA, M. L.; CUPERTINO, C. M. B. Práticas educacionais de atendimento ao aluno com altas habilidades/superdotaçáo. In: D. S. FLEITH (Org.). A construçáo de práticas educacionais para alunos com Altas habilidades/Superdotaçáo (Volume 1: Orientaçâo a professores, p. 67-80). Brasília, DF: MEC/SEESP, 2007.

SCHADER, R.; ZHOU, W. Minhas digitais do aprendizado [My learning printing]. (Trad. Angela M. R. Virgolim, tradução não publicada]. Storrs: Neag Center for Talent Development, University of Connecticut. 2006.

SEELEY, K. Gifted students at risk. In: L. K. SILVERMAN (Ed.), Counseling the gifted and talented (p. 263-275). Colorado: Love Publishing, 1993.

STARKO, A. J. It's about time: In-service strategies for curriculum compacting. Mansfield Center, CT: Creative Learning Press, 1986.

STERNBERG, R. J. A triarchic view of giftedness: Theory and practice. In: N. COLANGELO; G. A. DAVIS (Orgs.). Handbook of gifted education, 2nded., 43-53. Needham Heights, MA: Allyn \& Bacon. 1997.

TREFFINGER, D. J.; RENZULLI, J. S. Giftedness as potential for creative productivity: Transcending IQ scores. Roeper Review, 8 (3), 150-154. 1986.

VIRGOLIM, A. M. R. Creativity and intelligence: A study of Brazilian gifted and talented student. Unpublished doctoral dissertation, University of Connecticut, Storrs, Mansfield, CT, USA, 2005.

VIRGOLIM, A. M. R. Altas habilidades/Superdotação: Encorajando potenciais. Brasília: Ministério da Educaçấo, Secretaria de Educaçăo Especial - MEC/SEESP, 2007a.

VIRGOLIM, A. M. R. Uma proposta para o desenvolvimento da criatividade na escola, segundo o modelo de Joseph Renzulli. In: A. M. R.VIRGOLIM (Ed.). Talento Criativo: Expressão em múltiplos contextos (p. 159185). Brasília: Editora UnB, 2007 b.

VIRGOLIM, A. M. R. Intelligence (entry). In: B. KERR (Ed.), Encyclopedia of giftedness, creativity, and talent, v. 1, p. 472-476. Washington, DC: SAGE, 2009.

VIRGOLIM, A. M. R., FLEITH, D. S.; NEVES-PEREIRA, M. Toc, toc, plim, plim! Lidando com as emoçóes, brincando com o pensamento através da criatividade( $1^{\text {a }}$ ed). Campinas: Papirus, 1999.

WINNER, E. Crianças superdotadas: Mitos e realidades (Trad. Sandra Costa). Porto Alegre: Artes Médicas, 1998.

WHITMORE, J.R. Understanding a lack of motivation to excel. Gifted Child Quartely, 30 (2), 66-69. 1986. 


\section{Notas}

${ }^{1}$ A construção de Práticas Educacionais para Alunos com Altas Habilidades/ Superdotação. Disponível em: http://portal.mec.gov.br/index.php?option=com_content\&view=article\&id=12679\%3Aa-construcao-depraticas-educacionais-para-alunos-com-altas-habilidadessuperdotacao\&catid=192\%3Aseesp-esducacao-especial\& $\&$ Itemid $=860$

${ }^{2}$ The Interest-A-Lyser. (RENZULLI, 1997). Levantamento de Interesses. Instrumento traduzido e adaptado por Virgolim, não publicado.

${ }^{3}$ Learning Styles Inventory. Renzulli, J. S. \& Smith, L. H. (1978). $\odot$ Copyright Creative Learning Press. University of Connecticut, Storrs, CT, USA. Tradução e Adaptação não publicada: Angela Virgolim - Universidade de Brasília.

${ }^{4}$ Schader, \& Zhou, (2006). Minhas digitais do aprendizado [My learning printing]. Trad. Angela M. R.Virgolim [trabalho não publicado]. Storrs: Neag Center for Talent Development, University of Connecticut.

\section{Correspondência}

Angela Mágda Rodrigues Virgolim - Universidade de Brasília, Instituto de Psicologia, Departamento de Psicologia Escolar e do Desenvolvimento. Campus Universitário Darcy Ribeiro - Asa Norte. CEP: 70910-900 - Brasilia, Distrito Federal - Brasil.

E-mail: angela.virgolim@gmail.com

Recebido em 08 de maio de 2014

Aprovado em 20 de junho de 2014 
